DOI: https://doi.org/10.47405/mjssh.v6i7.850

\begin{tabular}{|c|c|}
\hline 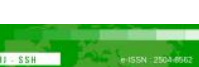 & Malaysian Journal of Social Sciences and Humanities (MJSSH) \\
\hline Malaysian Journal of & Volume 6, Issue 7, July 2021 \\
\hline (MJ. SSH) & e-ISSN : 2504-8562 \\
\hline & $\begin{array}{l}\text { Journal home page: } \\
\text { www.msocialsciences.com }\end{array}$ \\
\hline
\end{tabular}

\title{
Mengurus Perubahan Semasa Perintah Kawalan Pergerakan Bersyarat (PKPB) di Sebuah Sekolah Menengah: Suatu Pemerhatian Awal
}

\author{
Siti Syakirah Binti Samsudin1, Manimaran A/L Armugam1, Tai Mei Kin1 \\ 1Fakulti Pengurusan dan Ekonomi, Universiti Pendidikan Sultan Idris (UPSI)
}

Correspondence: Siti Syakirah Binti Samsudin (sitisyakir14@gmail.com)

\begin{abstract}
Abstrak
Kajian ini menggunakan reka bentuk tinjauan menerusi kaedah pemerhatian di sebuah sekolah menengah dalam daerah Batu Gajah di Negeri Perak. Populasi kajian terdiri daripada 102 orang murid Tingkatan Lima di sekolah tersebut. Pemerhatian dibuat ke atas peserta kajian berdasarkan tempoh masa yang tertentu yang telah ditetapkan. Oleh itu, dari kaedah pemerhatian, keputusan yang diperoleh adalah lebih tepat. Menerusi pemerhatian, Model Kompetensi Kepimpinan Perubahan (MKKP) telah digunakan oleh pengetua semasa berhadapan dengan perubahan dalam tadbir urus sekolah. Perintah Kawalan Pergerakan Bersyarat (PKPB) telah mengubah pembudayaan dan iklim sekolah menerusi kepimpinan pengetua. Kajian dijalankan setelah pembukaan semula sekolah bagi murid yang mengambil peperiksaan SPM dan STPM. Kepimpinan pengetua dapat dilihat menerusi pencapaian matlamat perubahan yang telah dirancang dari awal proses perubahan. Pengetua juga berjaya melakukan perubahan dengan cara yang kreatif dan proaktif terhadap sekolah tersebut. Hal ini dapat dilihat menerusi kepimpinan pengetua dalam menguruskan perubahan sekolah adalah amat penting kerana peranan pengetua sebagai individu yang bertanggungjawab secara langsung ke atas perubahan di sekolah.
\end{abstract}

Kata kunci: Perintah Kawalan Pergerakan Bersyarat (PKPB), COVID-19, kepimpinan pengetua

\section{Managing Current Changes of Conditional Movement Control Order (MCO) in a Secondary School: A Preliminary Observation}

\begin{abstract}
This study uses a survey design through observation method in a secondary school in Batu Gajah district in Perak. The study population consisted of 102 Form Five students in the school. Observations are made on the samples based on a specific time period that has been set. Therefore, from the observation method, the results obtained are more accurate. Through observation, the Change Leadership Competency Model (MKKP) has been used by principals when faced with changes in school governance. The Conditional Movement Control Order (PKPB) has changed the culture and climate of the school through the leadership of the principal. The study was conducted after the reopening of the school for students who took the SPM and STPM examinations. Principal leadership can be seen through the achievement of change goals that have been planned from the beginning of the change process. Principals also managed to make changes in a creative and proactive way towards the school. This can be seen through the leadership of the principal in managing school change is very important because the role of the principal as an individual who is directly responsible for change in the school.
\end{abstract}


Keywords: Conditional Movement Control Order (MCO), COVID-19, principal leadership

\section{Pengenalan}

Seluruh dunia sedang berhadapan dengan virus COVID-19. Hal ini tidak terkecuali pada negara Malaysia. Pada bulan Januari 2020, telah disahkan bahawa virus ini telah menular di Malaysia. Pada peringkat awal, kes-kes hanya terbatas kepada kes-kes import sahaja, namun pada awal bulan Mac, Malaysia digemparkan dengan kes-kes tempatan yang telah dijangkiti. Dalam beberapa minggu, Malaysia telah mencatat jumlah kumulatif terbesar jangkitan COVID-19 di Asia Tenggara pada akhir bulan Mac.

Perintah Kawalan Pergerakan (PKP) telah mula berkuat kuasa pada 16 Mac di seluruh negara. Ia bertujuan untuk mengurangkan penyebaran COVID-19 di seluruh negara. PKP telah dilanjutkan kepada dua minggu, sehingga tarikh 14 April disebabkan peningkatan kadar kes baharu meningkat setiap hari. Seterusnya, fasa PKP dilanjutkan sehingga 12 Mei 2020 apabila negara sudah mula melihat hasil yang positif daripada pelaksanaan perintah tersebut. Selepas itu, Perintah Kawalan Pergerakan Bersyarat (PKPB) dilaksanakan dengan memberikan sedikit kelonggaran kepada sektorsektor tertentu. PKPB dilaksanakan sehingga 10 Jun 2020 dan disambung dengan Perintah Kawalan Pergerakan Pemulihan (PKPP) sehingga 31 Disember 2020.

Bagi meneruskan kelangsungan sistem pendidikan, sekolah-sekolah mula dibuka semula secara berperingkat mulai 24 Jun dan keutamaan diberikan kepada murid yang mengambil peperiksaan awam seperti SPM dan STPM. KPM telah menyediakan garis panduan (SOP) sebagai langkah-langkah pencegahan awal antaranya semua murid dan warga sekolah memeriksa suhu ketika memasuki sekolah dan mengamalkan penjarakan sosial sekurang-kurangnya satu meter. Kajian ini bertujuan untuk mengenal pasti bagaimana pengetua mengurus perubahan yang berlaku pada PKPB di salah sebuah sekolah dalam daerah Batu Gajah di Negeri Perak.

\section{Sorotan Literatur}

Terdapat kajian telah dijalankan untuk menilai bagaimana pemimpin sekolah mengurus perubahan. Kajian yang dijalankan oleh Chang, Chen dan Chou (2017) bertujuan untuk mengkaji kepimpinan perubahan pengetua berdasarkan persepsi guru-guru sekolah dan bagaimana dimensi perubahan memberikan kesan terhadap perkembangan profesional guru. Terdapat 490 orang guru dari 41 buah sekolah rendah di New Taipei City (Taiwan)-menyertai kajian ini. Dapatan menunjukkan bahawa terdapat perbezaan antara jantina $(t=2.065, p=.039)$ iaitu guru lelaki mempunyai persepsi yang lebih tinggi terhadap kepimpinan perubahan yang diamalkan oleh pengetua. Dua aspek dalam kajian mereka iaitu membina persekitaran yang menyokong dan mengurus organisasi dan prestasi turut mencatatkan perbezaan dari segi jantina responden, manakala, komunikasi dan membentuk tindakan perubahan tidak menunjukkan perbezaan yang signifikan. Dari segi bagaimana kepimpinan perubahan pengetua memberikan kesan terhadap persepsi guru mengenai aktiviti pembangunan profesional mereka, analisis regresi menunjukkan bahawa pembangunan profesional guru boleh dijelaskan oleh kepimpinan perubahan pengetua sebanyak $23.3 \%$ daripada varians $(R 2=.232, F(1,451)=135.973$, $p=.000)$.

Kajian oleh Tai, Omar, Mohamad Sahari dan Khuan (2015) merupakan satu kajian yang dilaksanakan di Malaysia untuk mengenal pasti persepsi guru terhadap tahap kompetensi kepimpinan perubahan di sekolah menengah. Kajian ini melibatkan 47 sekolah menengah berprestasi tinggi di Malaysia. Kajian ini mendapati bahawa skor min bagi kompetensi pengetua ialah $4.66(\mathrm{SP}=.70)$ iaitu berada di tahap tinggi. Satu dapatan yang menarik dalam kajian ini ialah pengetua di sekolah berasrama penuh di bawah kategori sekolah berprestasi tinggi mencatat min paling tinggi $(\mathrm{M}=4.75, \mathrm{SP}=.71)$ berbanding dengan sekolah berprestasi tinggi kategori sekolah menengah harian $(\mathrm{M}=4.67, \mathrm{SP}=.66)$ dan sekolah 
menengah agama $(\mathrm{M}=4.51, \mathrm{SP}=.74)$. Dapatan kajian ini juga menunjukkan terdapat perbezaan signifikan antara komponen-komponen kepimpinan mengurus perubahan yang dikaji.

\section{Metod Kajian}

\section{Latar Belakang Sekolah}

Kajian ini dijalankan di sebuah sekolah menengah yang terletak di Daerah Batu Gajah, Perak. Sekolah ini berada di bawah seliaan PPD Kinta Selatan, Jabatan Pendidikan Negeri Perak. Sekolah ini memiliki 592 pelajar secara keseluruhan. Seramai 102 orang pelajar adalah Pelajar Tingkatan Lima. Ia mempunyai seramai 62 orang guru dan lapan staf sokongan. Pada asalnya sekolah mengamalkan dua sesi PdPc namun setelah berlaku COVID-19 ia telah diubah kepada satu sesi sahaja selaras dengan SOP yang telah dikeluarkan oleh KPM pada 13 Mac 2020. Secara fizikalnya, sekolah mempunyai empat blok bangunan yang digunakan untuk pentadbiran dan pembelajaran harian. Kini hanya menggunakan 2 blok sahaja sebagai blok pentadbiran dan pengurusan kawalan. Bagi memerangi penularan COVID-19, pihak sekolah telah melaksanakan perubahan dengan menetapkan arahan laluan murid untuk pejalan kaki sehala di seluruh kawasan sekolah; dan pematuhan murid terhadap arahan berdasarkan simbol yang telah ditetapkan berdasarkan garis panduan SOP yang dikeluarkan oleh KPM. Kedua-dua perkara di atas merupakan fokus utama dalam kajian ini.

\section{Kaedah Kajian}

Kajian ini menggunakan pendekatan kualitatif menerusi kaedah pemerhatian. Pendekatan pemerhatian yang digunakan dapat memudahkan pengkaji mengumpul maklumat atau data yang diperlukan. Pemerhatian dibuat ke atas Pengetua bagaimana mengurus perubahan di sekolah iaitu tempoh masa untuk pemerhatian ditetapkan dari 24 Jun 2020 hingga 24 Ogos 2020 iaitu selama tiga bulan.

Kepimpinan mengurus perubahan pengetua dinilai berdasarkan Model Kompetensi Kepimpinan Pengurusan Perubahan (MKKPP) yang dibina oleh Tai, Omar, Sahari dan Khuan (2014) yang telah dibina berdasarkan latar belakang sekolah tempatan. MKKPP memiliki empat fasa utama iaitu (i) pembentukan matlamat; (ii) pembangunan kapasiti; (iii) mengurangkan rintangan dan konflik perubahan; dan (iv) pembudayaan. Setiap fasa tersebut mempunyai tiga kompetensi yang penting tentang pengurusan perubahan seperti yang disenaraikan di jadual di bawah.

\section{Jadual 1: Model Kompetensi Kepimpinan Pengurusan Perubahan}

\begin{tabular}{ll}
\hline Fasa & Kompetensi \\
\hline Pembentukan matlamat & Menetapkan satu matlamat yang dapat dicapai oleh sekolah \\
& Menjelaskan rasional keperluan untuk perubahan \\
& Mempunyai hala tuju yang jelas tentang cara pencapaian matlamat \\
& perubahan \\
Pembangunan Kapasiti & Mengenal pasti kaedah untuk membangunkan kompetensi staf \\
& Menyediakan latihan berkaitan amalan 'coaching' dalam kalangan \\
& staf \\
& Memastikan staf berkemampuan menjalankan tugas baharu. \\
Mengurangkan rintangan & Meramalkan tingkah laku penentangan yang mengancam usaha- \\
dan konflik perubahan & usaha perubahan; \\
& Meyakinkan individu yang menentang perubahan; \\
& Mengurus konflik perubahan dengan memperoleh persetujuan \\
& daripada semua pihak \\
Pembudayaan & Menganalisis hasil mutakhir perubahan secara objektif; \\
& Mewujudkan peluang berkongsi amalan terbaik antara jabatan; \\
& Memastikan staf memberi sumbangan secara berterusan dalam \\
& perubahan yang dilakukan. \\
\hline
\end{tabular}


Menerusi MKKPP, pengetua telah menetapkan pembentukan matlamat yang rasional dan mempunyai hala tuju yang jelas kepada perubahan berdasarkan kemampuan sekolah yang boleh dicapai. Berdasarkan pembangunan kapasiti, mendapati bahawa pengetua telah membangunkan teknik latihan dalam kalangan staf untuk memastikan kemampuan staf menjalankan tugas baharu. Dalam mengurangkan rintangan dan konflik perubahan, pengetua telah meyakinkan staf mengenai kesan perubahan berupaya menghasilkan impak yang positif. Berdasarkan penjelasan ini, pengetua memperoleh persetujuan daripada semua staf yang terlibat. Perubahan yang dilaksanakan telah mewujudkan perkongsian amalan baik dan membina pasukan kerja yang mantap dan mampu bekerjasama serta memberikan sumbangan secara berterusan sehingga perubahan ini dapat membentuk satu budaya dalam amalan kerja di sekolah yang baharu.

\section{Hasil Pemerhatian Awal dan Perbincangan}

Pengetua adalah individu yang telah dilantik dari kalangan guru secara rasmi oleh KPM dan diberikan tugas untuk mentadbir serta mengetuai bagi sesebuah sekolah. Pengetua juga diberikan autonomi untuk menggunakan pelbagai kaedah bagi menguruskan segala bentuk sumber yang ada di sesebuah sekolah. Menurut Ibrahim (2001) pengetua merupakan tunggak utama pada sesebuah sekolah serta bertanggungjawab terhadap semua bentuk kegiatan yang dijalankan di dalam sekolah. Penularan wabak COVID-19 ini telah merubah corak persekitaran malah iklim dalam sekolah itu sendiri, pengetua sebagai pemimpin utama perlu menggerakkan sekolah walaupun perubahan perlu dikuatkuasakan di sekolah berdasarkan SOP yang diberikan oleh KPM. Perbincangan MKKPP dalam kajian ini meneroka pelbagai elemen yang berkait rapat dengan kuasa-kuasa yang perlu dipraktikkan oleh seorang pengetua.

Dalam kajian Tai (2013), satu dapatan menunjukkan bahawa matlamat sekolah merupakan satu elemen penting yang memberikan kesan kepada gaya kepimpinan sekolah. Melihat semula kepada domain dalam MKKPP, matlamat dirujuk sebagai satu elemen yang mempengaruhi pengetua sekolah. Dalam penulisan Mohan et al. (2020) aspek matlamat telah dibincangkan sejajar dengan pembentukan matlamat sekolah yang berperanan sebagai pusat PdPc yang perlu beroperasi sepanjang penularan wabak. Dalam perbincangan mereka, aspek-aspek MKKPP yang menjadi tumpuan dalam kajian ini dibincangkan dalam konteks peningkatan profesionalisme guru dan staf yang perlu diberi perhatian oleh pemimpin sekolah seiring dengan perubahan yang diinginkan. Mengikut Tai et al. (2015), perkembangan profesionalisme guru perlu menunjukkan elemen daripada matlamat sekolah dan keperluan kepimpinan perubahan dalam hal ini ialah untuk menghubungkan perubahan matlamat sekolah dalam masa krisis dengan latihan profesionalisme yang diberikan kepada guru. Oleh itu, pengetua telah memainkan peranannya sebagai pentadbir dengan memberikan penerangan dalam bentuk taklimat kepada semua guru-guru serta staf pentadbiran bahawa sekolah kini perlu mengikuti beberapa SOP yang sama sekali berbeza dengan apa yang pernah dilakukan sebelum COVID-19 melanda.

Dalam pada itu, kajian semasa turut mendapati peranan pengetua sebagai pemimpin instruksional adalah sangat kritikal dalam merancang serta mengelola operasi bagi setiap program sekolah termasuk penyampaian PdPc guru, mengawasi dan mempengaruhi perlaksanaan PdPc, menyelaras aktiviti dan menilai kemajuan serta prestasi keseluruhan dari masa ke semasa itu adalah rutin untuk pemimpin selaku pengetua. Mengikut kajian yang dijalankan oleh Chang et al. (2017), dua dimensi utama iaitu menyesuaikan organisasi dan prestasi dan berkomunikasi dan membentuk tindakan perubahan adalah berkait rapat dengan peranan pengetua dalam konteks instruksional. Dalam pemerhatian untuk kajian semasa, pengetua bukan bekerja bersendirian tetapi tugas tersebut digalas bersama pasukan kerja yang telah diagihkan dan ditentukan oleh hasil perbincangan bersama pengetua dan barisan pentadbir dengan membentuk jawatankuasa pelaksana baharu terutama untuk perubahan yang terjadi di sekolah. Barisan pemimpin sekolah telah menyediakan program untuk semua guru mendapatkan informasi dan bengkel yang boleh meningkatkan kemahiran guru untuk mengendalikan PdPc secara maya ketika berada di sekolah, kecuali untuk murid Tingkatan Lima yang telah bersekolah pada 24 Jun. Hal ini mengikut Mei Kin et al. (2018) berfungsi sebagai pemangkin kepercayaan perubahan yang 
mewujudkan organisasi dan prestasi yang sesuai serta komunikasi dan tindak perubahan yang berkesan.

Mengikut Lewin (dalam Baglibel et al., 2014) keperluan untuk perubahan telah diiktiraf dalam langkah pertama model perubahannya dengan menggunakan istilah penyahbekuan. Menurut Lewin (dalam Baglibel et al. 2014), kebanyakan orang cenderung menjadi selesa dalam persekitaran yang tidak berubah. Perkara ini telah dibincangkan dalam Tai et al. (2015) sebagai satu punca utama wujudnya model MKKPP sebagai usaha untuk mengatasi keadaan beku ini. Apabila pemimpin mampu menyedari bahawa keadaan sedia ada tidak lagi relevan dan berkesan maka, dengan menyedari keperluan untuk membuang tingkah laku lama, struktur, proses dan budaya sekali gus mewujudkan dorongan untuk perubahan (Chang et al. 2017). Peringkat ini penting bukan sahaja untuk meningkatkan keupayaan organisasi untuk merasai keperluan untuk perubahan, tetapi juga untuk mengumpul sokongan kepada idea perubahan. Kajian ini telah meneroka dorongan perubahan ini dengan mengkaji perubahan daripada persepsi pelajar di sekolah-sekolah yang terlibat dan menerusi perubahan tersebut satu aspek yang penting ialah mewujudkan perubahan yang mengatasi rintangan dan konflik.

Dalam menangani konflik, kajian oleh Kin dan Kareem (2013) menunjukkan bahawa pengetua yang mengambil bahagian dalam kajian mereka tidak menunjukkan kemahiran menangani dan mengurus rintangan dan halangan. Mengikut mereka, pengetua sering kali gagal menjangkakan halangan dari segi tindakan guru dan pelajar, memberikan keyakinan kepada mereka yang menjadi halangan dan mengurus konflik perubahan dengan mendapatkan persetujuan semua pihak yang terlibat. Dalam kajian ini, masalah yang sama didapati apabila pengetua tidak dapat menekankan keperluan guru dan pelajar untuk bersama dengannya untuk membawa perubahan yang wujud dalam pengurusan sekolah ketika penularan wabak. Ia membawa kepada aspek pembudayaan yang tidak dapat diterapkan sepenuhnya oleh pengetua. Pembudayaan pemimpin dalam membawa perubahan merangkumi tugas pengetua sebagai penentu matlamat, pencadang, pemangkin, penghubung, penyokong, koordinator, jurulatih, penilai, pengurus, pemberi maklumat dan model. Tugas-tugas tersebut sangat relevan semasa melaksanakan perubahan di sekolah kerana ia digunakan untuk mengurangkan rintangan dan konflik yang dihadapi di sekolah (Fullan, 1982). Fullan (2016) turut menawarkan maklumat penting mengenai kebolehan pengetua untuk mengubahsuai stail kepimpinan mengikut situasi di sekolah dengan sumber tenaga yang ada di sekolah ia dapat diukur apabila pengetua dapat bekerjasama dengan komuniti setempat yang terdiri daripada Ibu bapa murid-murid menerusi Persatuan Ibu Bapa dan Guru (PIBG).

Kajian semasa mendapati bahawa kepercayaan yang diperoleh oleh pengetua daripada PIBG telah mengurangkan konflik ibu bapa yang sentiasa gusar akan keselamatan kesihatan anak-anak jagaan mereka sewaktu berada di sekolah. Bagi mengurangkan rintangan dan konflik perubahan, pengetua sentiasa menyelia dan memberikan motivasi kepada semua guru dan staf serta komuniti PIBG bahawa sekolah merupakan salah satu kawasan yang bebas daripada wabak COVID-19. Unsur pembudayaan adalah penentu kepada kejayaan perubahan dan keberkesanan sesebuah sekolah (Bolman \& Deal, 1990; Sharifah, 2003). Pembudayaan sesebuah sekolah dibentuk oleh warga sekolah tersebut, oleh itu, pembudayaan boleh diubah dan kepimpinan pengetua adalah individu yang paling berpengaruh untuk mengubah dan mencorakkan budaya di sesebuah sekolah. Menurut Sergiovanni (2000) pengetua adalah kunci utama dalam pembentukan budaya sesebuah sekolah. Pengetua akan berusaha untuk membentuk pembudayaan norma baharu di sekolah menerusi SOP yang telah digariskan oleh KPM. Menerusi pemerhatian, pengetua mengubah pembudayaan sekolah kepada norma baharu dengan cara bergerak dalam pasukan secara proaktif dan sefahaman antara semua guru dan staf bahawa segala prosedur perlu dipatuhi bagi menjamin keselamatan kesihatan dalam sekolah terutamanya bagi muridmurid. Amalan untuk menyemak suhu murid di hadapan pintu pagar dan pemakaian topeng muka serta mengagihkan nyahkuman di hadapan pintu pagar sekolah oleh guru yang bertugas telah menjadi rutin harian mereka. Pemikiran yang cergas pengetua telah membuat simulasi terlebih dahulu sebelum pembukaan sekolah. Ia termasuk simulasi proses PdPc di dalam kelas, bahkan laluan murid untuk ke tandas dan kantin. Pengetua telah membuat perubahan yang agak ketara dengan pembudayaan jalan sehala dalam sekolah, ia termasuk untuk murid, guru, staf dan juga pengetua sendiri. Pengambilan murid oleh guru sains untuk membawa murid-murid memasuki makmal sains telah dijadikan rutin budaya untuk penggunaan makmal sains. Pengetua berjaya mengawal pergerakan murid dan guru 
semasa sesi PdPc berjalan dengan pembudayaan diberikan dahulu dalam bentuk latihan kepada guruguru sebelum pembukaan semula sekolah kepada murid Tingkatan Lima. Murid-murid telah dilazimkan dengan simbol-simbol yang terdapat pada persekitaran sekolah, bahkan terdapat segelintir guru yang memasukkan pengajaran mereka mengenai setiap maksud simbol-simbol terbabit di dalam PdPc mereka.

\section{Kesimpulan}

Hakikatnya, MKKPP adalah model yang diuji secara empirik yang selaras dengan persekitaran pendidikan budaya tempatan Malaysia. Ia memberi panduan kepada pengamal sebagai maklum balas yang berguna dalam merancang, merancang, melaksana dan menilai program latihan dan pembangunan masa depan untuk pengetua sekolah. Secara khusus, ini adalah alat analisis keperluan latihan yang berkesan yang disesuaikan untuk pengetua sekolah untuk mengenal pasti keperluan mereka yang berbeza pada program latihan yang relevan pada tahap perubahan yang berbeza. Dapatan kajian semasa dan Mei Kin et al. (2018), Chang et al. (2017) dan Tai et al. (2015) mempunyai implikasi yang luas untuk membangunkan satu pendekatan yang dapat diamalkan di sekolah-sekolah yang menerima perubahan dalam konteks pendidikan terutamanya dalam mengurus perubahan yang dibawa oleh pandemik yang melanda dunia hari ini. Di samping itu, Skala MKKPP adalah alat yang menawarkan satu instrumen yang kukuh dan terbukti berkesan kepada pemimpin sekolah agar dapat mengamalkan kepimpinan perubahan yang berkesan.

Kepimpinan pengetua dapat dilihat menerusi pencapaian matlamat perubahan yang telah dirancang dari awal proses perubahan. Hasil dari pemerhatian, pengkaji mendapati pengetua berjaya mengekalkan tahap kesediaan perubahan yang tinggi pada murid, guru dan staf. Pengetua juga berjaya melakukan perubahan dengan cara yang kreatif dan proaktif terhadap sekolah tersebut. Ia dibuktikan menerusi keputusan analisis data yang diperoleh iaitu sembilan puluh lima peratus (95\%) murid telah benar-benar berjaya mematuhi SOP berjalan di laluan pejalan kaki dalam kawasan sekolah secara sehala dan sembilan puluh peratus $(90 \%)$ murid menguasai maksud simbol yang digunakan sebagai arahan kata kerja berdasarkan panduan SOP yang disediakan oleh KPM. Manakala para guru telah menjadikan perubahan ini sebagai rutin harian dan amalan baharu yang didasari oleh SOP dari KPM. Menerusi pemerhatian didapati, guru-guru akan hadir ke sekolah seawal 6.45 pagi untuk bertugas di tempat yang telah ditetapkan bergantung pada jadual yang telah disusun atur oleh pihak pentadbir. Pengetua telah melakukan perubahan pembudayaan yang baharu pada sekolah tersebut bermula dari amalan masuk dan keluar dari pintu sekolah. Ia dipandu oleh penggunaan MKKP oleh pengetua semasa proses perubahan. MKKP yang digunakan oleh pengetua telah merubah perspektif guru terhadap perubahan yang perlu dilakukan, hal ini termasuk persepsi dari murid-murid terhadap perubahan yang dilaksanakan oleh pentadbiran pengetua. Komunikasi berkesan dan interaksi dua hala antara kepimpinan pengetua dengan guru dan murid-murid serta PIBG telah menghasilkan kepercayaan yang kukuh untuk pengetua melakukan pembentukan perubahan pada matlamat sekolah tersebut. Hal ini dapat dilihat bahawa kepimpinan pengetua untuk menguruskan perubahan sekolah amat penting. Pengetua ialah individu yang bertanggungjawab secara langsung ke atas perubahan pada operasi dan pelaksanaan dasar yang dirancang dan ingin dicapai (Mohd Izaham, 2007). Perubahan yang berlaku adalah berpunca dari peranan kepimpinan pentadbiran pengetua kerana pengetua dianggap sebagai agen perubahan yang utama dalam menyediakan persekitaran sekolah yang kondusif, walau pun negara masih dilanda COVID-19. Oleh itu, pengetua sentiasa dilihat bersedia terutama menghadapi segala cabaran dan konflik perubahan dalam mengimplementasikan perubahan baharu dalam sistem pendidikan di sekolah mereka. Keseluruhannya, kepimpinan pengetua merujuk kepada segala amalan budaya tingkah laku dari perancangan pengetua yang jelas untuk disampaikan kepada murid, guru dan staf bertujuan mempengaruhi, memberi bimbingan dan dorongan kepada murid, guru dan staf dalam usaha perubahan yang dapat menambah baik dan meningkatkan proses PdPc untuk mencapai matlamat perubahan yang telah dirancang. Ini termasuk untuk memastikan pelaksanaan sesuatu perubahan pendidikan di sekolah berjaya mencapai matlamat di sekolah berdasarkan SOP yang telah ditetapkan oleh KPM sewaktu berlakunya penularan wabak COVID-19. 


\section{Rujukan}

Armenakis, A. A.; Harris, S. G.; Mossholder, K. W. 1993. Creating readiness for organizational change, Human Relations 46(6): 681-703. http://dx.doi.org/10.1177/001872679304600601

Baglibel, M., Samancioglu, M., Ozmantar, Z. K., \& Hall, G. E. (2014). The Relationship Between School Principals' Perceived Change Facilitator Styles and Teachers' Attitudes Towards Change. International Studies in Educational Administration (Commonwealth Council for Educational Administration \& Management (CCEAM)), 42(3).

Bhattacharyya, E. (2019). Leadership Competencies and Leadership Style in Aspiring Cluster Schools of Excellence. Pertanika Journal of Social Sciences \& Humanities, 27(2).

Bolman, L. G., \& Deal. T. E. (1990). Leadership orientations instrument. San Francisco: JosseyBass

Bond, M. A., \& Lockee, B. B. (2014). Building virtual communities of practice for distance educators. New York: SpringerBouckenooghe,

Chang, D. F., Chen, S. N., \& Chou, W. C. (2017). Investigating the Major Effect of Principal's Change Leadership on School Teachers' Professional Development. IAFOR Journal of Education, 5(3), $139-154$.

Collerette et al. (2006). A successful IT Change in a Police Service. Journal of Change Management, 6(2); 159-179.

D., G. Devos \& H. Van den Broeck (2009). Organizational Change Questionnaire-Climate of Change, Processes, and Readiness: Development of a New Instrument. Journal of Psychology, 143(6), 559-599.

Davis, G. (2019). Exploring the Strategies Executive Leaders Need to Reduce Intergenerational Friction in a Business Organization (Doctoral dissertation, Colorado Technical University).

De Jager, P. (2001). Resistance to change: A new view of an old problem. The Futuristic, 35, 24-27

Dent, E. B., and Goldberg, S. G. (1999). Resistance to change: A limiting perspective. J. Appl. Behav. Sci. 35, 45-47. doi: 10.1177/0021886399351005

Deutschman (2007). Change or die: the three keys to change at work and life. New York: Harper Collins

Dwyer, C.D. (1984). The Search for Instructional Leadership: Routines and. Subtleties in the Principal's Role. Educational Leadership, 41(5), 33-. 37.

Eggen dan Kauchak (2013) Educational Psychology: Windows on Classrooms, 9th Edition. Paul Eggen, University of North Florida. Don Kauchak, University of Utah.

Eisenbach, R. K.; Watson, K.; Pillai, R. 1999. Transformational leadership in the context of organizational change, Journal of Organizational Change Management, 12(2), 80-88. http://dx.doi.org/10.1108/09534819910263631

Fernandez, A. A., \& Shaw, G. P. (2020). Academic Leadership in a Time of Crisis: The Coronavirus and COVID-19. Journal of Leadership Studies, 14(1), 39-45.

Fullan, M. (1982). The Meaning of Educational Change. New York: Teachers College Press.

Fullan, M. (2007). The new meaning of educational change (4th ed.). New York, NY: Teachers College Press.

Fullan, M. (2014). The principal: Three keys to maximising impact (1st ed.). San Francisco, CA: Jossey-Bass.

Fullan, M. (2016). The elusive nature of whole system improvement in education. Journal of Educational Change, 17(4), 539-544.

Fullan, Michael (2004) Leading in a Culture of Change.

Gaubatz, J. A., \& Ensminger, D. C. (2017). Department chairs as change agents: Leading change in resistant environments. Educational Management Administration and Leadership, 45, 141-163. http://dx.doi:10.1177/1741143215587307

Hall, G. E., \& Hord, S. (2011). Implementing change: Patterns, principles, and potholes ( $3^{\text {rd }}$ ed.). Boston, MA: Pearson.

Hall, G. E., \& Hord, S. M. (2015). Implementing change: Patters, principles, and potholes (4th ed.). Boston, MA: Pearson.

Hargreaves, A., \& Fullan, M. (2012). Professional capital: Transforming teaching in every school. New York, NY: Teachers College Press. https://portal.mda.gov.my/documents/ukk/1394-teksperutusan-khas-yab-pm-10042020/file.html 
Ibrahim Mamat. 2001. Pengetua sekolah menangani isu dan cabaran kepimpinan. Ed. ke-2. Subang Jaya: Kumpulan Budiman Sdn. Bhd.

Kin, T. M., \& Kareem, O. A. (2013). Principal change leadership competencies: a study in malaysian high performing secondary school. Journal of Education and Practice, 4(27), 101-116.

Klarner, P., Probst, G. and Soparnot, R. (2008). Organizational Change Capacity in Public Services: The Case of the World Health Organization. Journal of Change Management, 8(1): 57-72.

Leithwood, K., \& Jantzi, D. (2006). Transformational school leadership for large-scale reform: Effects on students, teachers, and their classroom practices. School Effectiveness and School Improvement, 17, 201-227. doi:10.1080/09243450600565829

Leithwood, K., \& Seashore Louis, K. (2012). Linking leadership to student learning. San Francisco, CA: Jossey-Bass.

Mann, D. (2009), "The missing link: lean leadership", Frontiers of Health Services Management, 26 (1), 15-26.

Mareena Mohamad,(2011). Tinjauan Hubungan Gaya Kepimpinan Dengan Komitmen Organisasi. Eksplanasi Vol.6 No.1 (Maret 2011), 17-18. ISSN: 2087-9474. pada Ogos 15, 2012 dan Oktober 10, 2014 daripada http://www.safod.org/images/LCNamibia.pdf.accessed

Mei Kin, T., Abdull Kareem, O., Nordin, M. S., \& Wai Bing, K. (2018). Principal change leadership competencies and teacher attitudes toward change: the mediating effects of teacher change beliefs. International Journal of Leadership in Education, 21(4), 427-446.

Mohan, G., McCoy, S., Carroll, E., Mihut, G., Lyons, S., \& Mac Domhnaill, C. (2020). Learning for all? Second-Level education in Ireland during COVID-19. Economic and Social Research Institute (ESRI) Research Series.

Mohd Izaham,(2007). Jurnal Pendidikan Malaysia 43(1)(2018): 17-23DOI: http://dx.doi.org/10.17576/JPEN-2018-43.01-03

Mohd Shahar, S. (1991). "Konflik Organisasi: Pandangan dan Penyelesaian Mengikut Alternatif Islam", dalam Shafie Mohd Salleh dan Mohd Affandi Hassan (ed.). Kecemerlangan Pentadbiran: Dasar dan Amalan dalam Islam. Kuala Lumpur: Institut Tadbiran Awam Negara

Mourier, P. and Smith, M. (2001) Conquering organizational change. Atlanta: CEP Press. In

Naseri, H. (2019). The Role of the Adventurer Manager In Order To Coordinate the Mind, Creativity and Change Management. International Journal for Modern Trends in Science and Technology, 5(04).

Oreg, S. (2003). Resistance to change: Developing an individual differences measure Journal of Applied Psychology, 88, 680-693. doi:10.1037/0021-9010.88.4.680

Oreg, S., \& Sverdlik, N. (2011). Ambivalence toward imposed change: the conflict between dispositional resistance to change and the orientation toward the change agent. Journal of Applied Psychology, 96(2), 337-339.

Parry, B.S. (1998) Just What Is a Competency And Why Should You Care Training, 35, 58-64.

Podsakoff, P. M.; MacKenzie, S. B.; Bommer, W. H. (1996). Transformational leader behaviors and substitutes for leadership as determinants of employee satisfaction, commitment, trust, and organizational citizenship behaviors. Journal of Management, 22, 259-298.

Robbins, P.S. (1993). Organizational Behavior. USA: Prentice Hall International Inc.

Sartori, R., and Tacconi, G. (2017). Guest editorial. Carrying out studies on competence-based training for career development. Eur. J. Train. Dev. 41, 2-7. doi: 10.1108/EJTD-07-2016-0050

Sartori, R., Tacconi, G., and Caputo, B. (2015). Competence-based analysis of needs in VET teachers and trainers: an Italian experience. Eur. J. Train. Dev. 39, 22-42. doi: 10.1108/EJTD-092013-0089

Sharifah Md. Noor, (2003). Creativity of arts education teachers in Malaysia. Pertanika Journal of Social Science \& Humanities. 11 (1): 11-17.

Tai, M. K., Omar, A. K., Mohamad Sahari, N., \& Khuan, W. B. (2015). Teacher change beliefs: Validating a scale with structural equation modelling. School Leadership and Management, 35, 266-2

Walberg, H. J. (1984). Improving the productivity of America's schools. Educational Leadership, $41(8), 19-27$.

Želvys, R., \& Esenova, K. (2019). Mapping priority areas for the development of leadership competencies of school principals. Pedagogika, 135(3), 200-216. 